\title{
Studies on digenetic Trematodes of Vertebrates
}

\author{
Part. I. On four Trematode parasites of turtles
}

\author{
by Anis JAHAN \\ Department of Zoology, University of Lucknow, Lucknow (India)
}

\begin{abstract}
Résumé
Un grand nombre de Trématodes ont été récoltés dans l'intestin de tortues d'eau douce provenant du fleuve Gomati à Lucknow. Ils appartiennent à trois genres: Neopronocephalus Mehra 1932; Cephalogonimus Poirier 1886, et Telorchis Mehra et Bokhari 1932. N. kachugai est nouvelle pour la science. N. gangeticus, $N$. mehri et $N$. rotundus sont considérés comme synonymes de $N$. triangularis Mehra, 1932.
\end{abstract}

\section{Summary}

A large number of Trematodes parasites were collected from the intestine of fresh water turtles obtained locally from river Gomati at Lucknow. These belong to three genera: Neopronocephalus Mehra, 1932 ; Cephalogonimus Poirier, 1886 and Telorchis Mehra and Bokhari, 1932. Cf. the four species described here, Neopronocephalus kachugai $\mathrm{n}$. sp. is new to Science. Neopronocephalus gangeticus Mehra, 1932, N. mehri Chatterji, 1936 and N. rotundus Siddiqi, 1965 have been considered as synonym of $N$. triangularis Mehra, 1932.

Acknowledgements: The work as been carried out under the direction of Dr. (Miss) Vinod Agrawal, M. Sc., Ph. D. ; Department of Zoology ; University of Lucknow; Lucknow. The author is deeply indebted to her for her valuable help and encouragement. Thanks aré also dué to Dr. S.P. Gupta for giving useful suggestions in the preparation of the manuscript.

The paratype and holotype specimens of the forms described in this paper will be depositéd in Dr. G. S. Thapar's Helminthological collection, Lucknow, U.P. India. 
FAMILY : PRONOCEPHALIDAE Looss, 1902

\section{Neopronocepbalus kacbugai n.sp.}

Plate. I. (Figs. 1-3)

Numerous specimens were collected from the intestine of a fresh water turtle Kachuga dhongoka at Lucknow.

Description : Body small, plump shaped, truncated at posterior end. Cephalic region distinct and separated from body by prominent constrictions : encircled by head collar, interrupted mid ventrally, 1.42 to $3.22 \mathrm{~mm}$. long, 0.56 to $2.0 \mathrm{~mm}$. wide. Oral sucker terminal, oval, 0.08 to $0.15 \mathrm{~mm}$. long, 0.1 to $0.2 \mathrm{~mm}$. wide. Esophagus narrow, long, tubular, 0.32 to $0.58 \mathrm{~mm}$. long. Intestinal caeca simple curving inwards in region of testes or runing dorsal to them and outwards in post testicular region, terminating upon level of vitellaria or a little posterior to them.

Testes two symmetrical, oval, entire, equal or subequal, intercaecal, lateral to caeca in mid region of body. Right testis, 0.25 to $0.54 \mathrm{~mm}$. long, 0.24 to $0.45 \mathrm{~mm}$. wide at 0.68 to $1.25 \mathrm{~mm}$. from anterior extremity. Left testis 0.29 to $0.52 \mathrm{~mm}$. long, 0.22 to $0.42 \mathrm{~mm}$. wide at 0.67 to $1.24 \mathrm{~mm}$. from anterior extremity. Cirrus sac oval 0.22 to $0.51 \mathrm{~mm}$. long, 0.13 to $0.25 \mathrm{~mm}$. wide, lying obliquely, intercaecal, extending from genital pore upto anterior or middle region of testes. Vesicula seminalis externa slender tube lying coiled external to cirrus sac. Vesicula seminalis interna large, globular, 0.13 to $0.33 \mathrm{~mm}$. long, 0.05 to $0.9 \mathrm{~mm}$. wide. Pars prostatica small, globular, 0.04 to $0.09 \mathrm{~mm}$. long, 0.07 to $0.075 \mathrm{~mm}$. wide, continues forward as an ejaculatory duct, 0.06 to $0.13 \mathrm{~mm}$. long. Genital pore on left side of body, intercaecal, caecal or extracaecal, close to intestinal bifurcation, 0.47 to $0.80 \mathrm{~mm}$. from anterior extremity.

Excretory vesicle V-shaped, with thick short branches; excretory pore subterminal.

Ovary oval, entire, postequatorial, median or slightly on right side of body, post testicular, 0.16 to $0.30 \mathrm{~mm}$. long, 0.13 to $0.35 \mathrm{~mm}$. wide, at 0.30 to $0,97 \mathrm{~mm}$, from posterior extremity. Oviduct arises from its posterior side opening at oötype. Receptaculum seminis large, globular, lying just behind ovary, either overlapping or slightly away from it, 0.13 to $0,35 \mathrm{~mm}$. long, 0.05 to $0.09 \mathrm{~mm}$. wide. Vitellaria follicular, 9 to 14 , lying immediately behind either testes, lateral or ventral to caeca. Uterus arises from oötype, coiled behing ovary passing between ovary and left testis and then between testes; passes anteriorly to open at genital pore. Metraterm distinct and well developed. Eggs oval, non operculated, 0.025 to $0.036 \mathrm{~mm}$. long, 0.012 to $0.021 \mathrm{~mm}$. wide.

Host : Kachuga dhongoka (Gray).

LOCATION : Intestine.

LOCALITY : Lucknow.

Discussion: There are three species in the genus Neopronocephalus Mehra, 1932, N. triangularis Mehra, 1932, N. gangeticus Mehra, 1932, N. rotundus Siddiqi, 1965, 
from India and $N$. mehri Chatterji, 1936, from Rangoon, all from fresh water turtles. Chatterji (1936) distinguished $N$. mehri from $N$. triangularis and $N$. gangeticus in the relative size of body, in the structure of cephalic region and collar, the number of
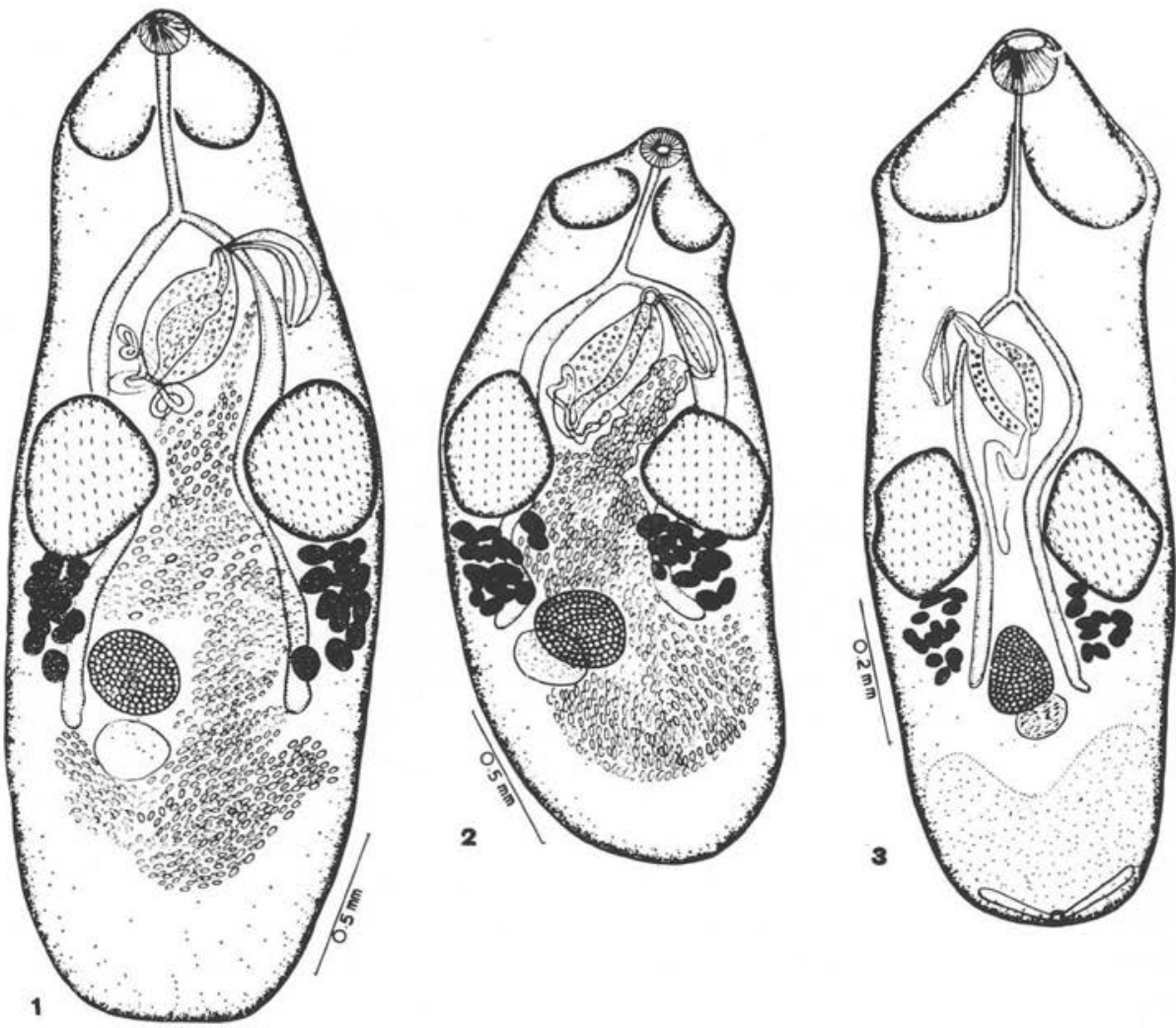

Pl. 1. Figs 1-3. - Neopronocephalus kachugai n. sp.

FIG. 1. - Entire. Ventral view. Genital pore intercaecal and intestinal caeca extending beyond ovary

FIG. 2. - Entire. Ventral view. Genital pore on intestinal caeca and intestinal caeca extending upto middle of ovary.

FIG. 3. - Entire. Dorsal view. Genital pore extracaecal and Intestinal caeca extending upto hind end of ovary

vitelline glands and the shape and position of excretory pore. Siddiqi (1965) distinguished $N$. rotundus from Indian forms in smaller body size and shape, size of oral sucker and from $N$. mehri in having ovary with an irregular outline, smaller cirrus sac and extracaecal testes. In the opinion of author the distinguishing characters pointed out are too variable and of no importance. Accordingly all the three species fall into the synonymy with $N$. triangularis (Table. I). 
The new form has a close resemblance to $N$. triangularis in body shape, in having cephalic region triangular, in having pear shaped cirrus pouch, in having equal or subequal testes and in having postequatorial ovary but however differs from it in the possession of a well-developed receptaculum seminis and in the extension of intestinal caeca behind the ovary.

Accordingly it is regarded as new with the specific name Neopronocephalus kachugai n. sp.

FAMILY CEPHALOGONIMIDAE Nicoll, 1915

\section{Cepbalogonimus kumarus Gupta, 1954}

Plate. 2. (Fig. 1)

Only three specimens of this form were collected from the intestine of a tortoise Lissemys punctata punctata at Lucknow.

Description : Body elliptical with broad anterior and narrow posterior ends, 1.85 to $2.08 \mathrm{~mm}$. long, 0.66 to $0.72 \mathrm{~mm}$. wide. Cuticle covered with backwardly directed spines, more closely arranged in preovarian region than behind it. Oral sucker spherical or globular, 0.15 to $0.16 \mathrm{~mm}$. long, 0.17 to $0.18 \mathrm{~mm}$. wide. A small prepharynx present. Pharynx small muscular oval structure, 0.05 to $0.06 \mathrm{~mm}$. long, 0.055 to $0.06 \mathrm{~mm}$. wide. Esophagus absent. Intestinal caeca run posteriorly along lateral sides of body terminating a little distance beyond posterior testis at a distance of 0.55 to $0.62 \mathrm{~mm}$. from posterior extremity. Ventral sucker smaller than oral sucker, 0.13 to $0.14 \mathrm{~mm}$. long, 0.14 to $0.15 \mathrm{~mm}$. wide to 0.48 to $0.56 \mathrm{~mm}$. from anterior extremity.

Genital pore median at anterior end of body, infront of oral sucker.

Excretory pore terminal at posterior extremity of body. Excretory bladder Yshaped, median stem extends upto hind end of posterior testis where it bifurcates into lateral cornua.

Testes rounded or oval, placed one behind other in middle region of body between intestinal caeca. Anterior testis larger, smaller or equal to posterior testis, 0.13 to $0.16 \mathrm{~mm}$. long, 0.23 to $0.24 \mathrm{~mm}$. wide at 0.83 to $0.92 \mathrm{~mm}$. from anterior extremity. Posterior testis at 0.04 to $0.06 \mathrm{~mm}$. from anterior testis, 0.15 to $0.18 \mathrm{~mm}$. long, 0.22 to $0.23 \mathrm{~mm}$. wide. Cirrus sac large, elongated, lying obliquely in space between oral and ventral suckers, 0.66 to $0.73 \mathrm{~mm}$. long, 0.11 to $0.12 \mathrm{~mm}$. wide, broader posteriorly and towards anterior end becoming narrower. Vesicula seminalis lying in basal part of cirrus sac, two distinct portions demarcated by a constriction. Proximal part larger than distal. Pars prostatica and ejaculatory duct long tubular structures. Pars prostatica surrounded by prostate gland cells.

Ovary lying close to postero lateral border of ventral sucker to right median line, giobular or oval, 0.12 to $0.13 \mathrm{~mm}$. long, 0.13 to $0.155 \mathrm{~mm}$. wide. Receptaculum seminis lying behind ovary to left of median line, 0.08 to $0.11 \mathrm{~mm}$. long, 0.09 to 
$0.13 \mathrm{~mm}$. wide. Vitellaria extracaecal, extending midway between oral sucker and ventral sucker to hind end of posterior testis. Uterus much coiled, its descending limb passes through space between ovary and anterior testis and confined to right side

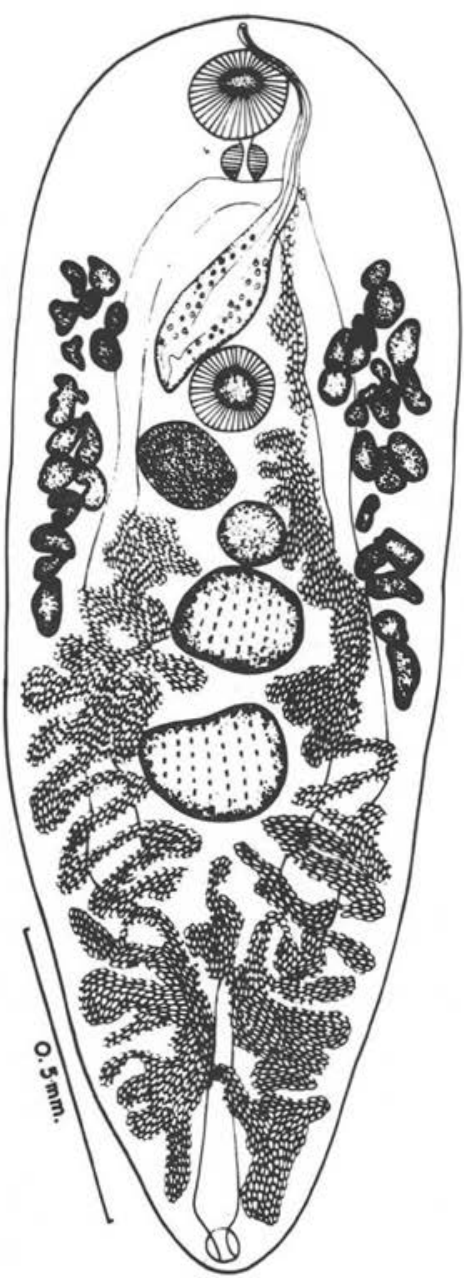

Pl. 2. Fig. 1. - Cephalogonimus kumarus Gupta, 1954 Entire. Ventral view.

of body while ascending limb to left side proceeding forward along intestinal caeca. In posttesticular region coils of uterus arranged in such a way and so full of eggs that difficult to make out descending and ascending limbs. Eggs oval, $0.03-0.04 \mathrm{~mm}$. long, 0.018-0.023 mm. wide. 


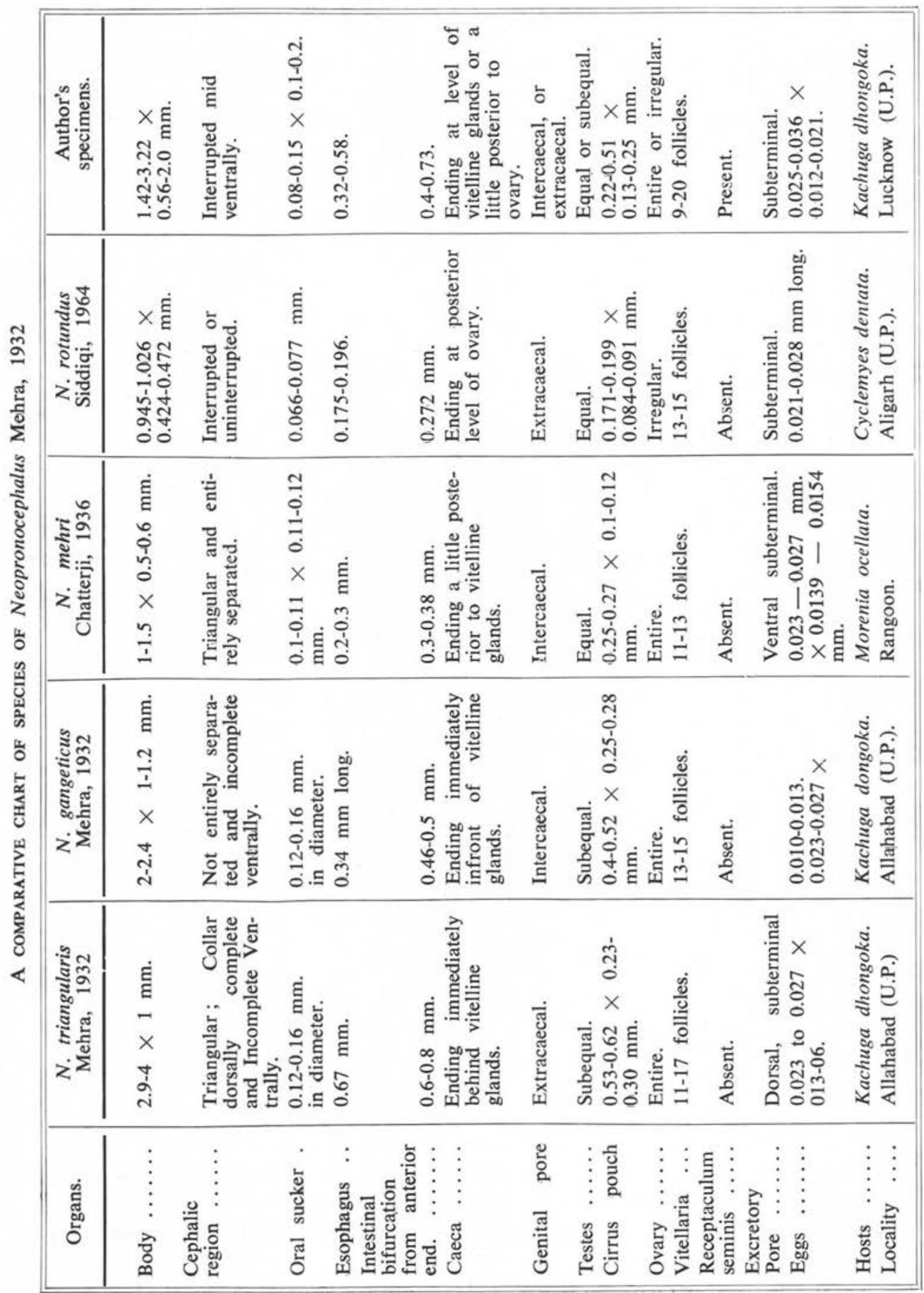


Host : Lissemys punctata punctata (Bonnaterre).

LOCATION : Intestine.

LOCALITY : Lucknow.

Discussion : The present form belongs to Cephalogonimus kumarus Gupta, 1954, but differs from it in the absence of esophagus, in having ovary separate from ventral sucker instead of being overlapped, in the extension of vitellaria upto anterior end of hind testis instead of upto middle of anterior testis and in having receptaculum seminis pretesticular. These differences are considered as specific variations.

FAMILY TELORCHIIDAE Stunkard, 1924

\section{Telorcbis pellucidus Mehra and Bokhari, 1932 \\ Plate. 3 (Fig. 1-2)}

Six specimens were collected from the intestine of Kachuga dhongoka from river Gomati at Lucknow.

Description : Body slender, elongated with rounded extremities, 1.53 to $4.62 \mathrm{~mm}$. long, 0.36 to $0.93 \mathrm{~mm}$. wide. Cuticle covered with small spines extending back to level of anterior testis. Oral sucker subterminal, spherical, 0.09 to $0.19 \mathrm{~mm}$. long, 0.11 to $0.22 \mathrm{~mm}$. wide. Prepharynx small thin walled, 0.01 to $0.04 \mathrm{~mm}$. long. Pharynx spherical or globular, 0.05 to $0.88 \mathrm{~mm}$. long, 0.06 to $0.7 \mathrm{~mm}$. wide. Esophagus slender, 0.03 to $0.08 \mathrm{~mm}$. long. Intestinal caeca simple, slender, crenated extending at unequal levels behind posterior testis. Ventral sucker spherical or subspherical, smaller than oral sucker, median of slightly to one side, 0.04 to $0.16 \mathrm{~mm}$. long, 0.05 to $0.055 \mathrm{~mm}$. wide at 0.55 to $1.10 \mathrm{~mm}$. from anterior extremity.

Genital pore median or submedian, preacetabular, 0.85 to $1.77 \mathrm{~mm}$. from anterior extremity.

Excretory pore at hind end of body. Excretory bladder Y-shaped, bifurcating behind ovary.

Testes lobed, tandem, intercaecal near posterior extremity. Anterior testis equal or smaller than posterior testis, 0.11 to $0.32 \mathrm{~mm}$. long, 0.13 to $0.40 \mathrm{~mm}$. wide at 1.05 to $4.05 \mathrm{~mm}$. from anterior end. Posterior testis 0.05 to $0.50 \mathrm{~mm}$. long, 0.05 to 0.07 $\mathrm{mm}$. wide at 0.19 to $0.54 \mathrm{~mm}$. from hind end. Cirrus pouch elongated or crescent shaped, extending upto anterior or middle of ovary and between ventral sucker and ovary, 0.38 to $0.98 \mathrm{~mm}$. long, 0.12 to $0.28 \mathrm{~mm}$. wide. Vesicula seminalis spirally coiled, 0.02 to $0.04 \mathrm{~mm}$. long. Pars prostatica elongated, tubular, 0.07 to $0.135 \mathrm{~mm}$. long, 0.015 to $0.035 \mathrm{~mm}$. wide. Ejaculatory duct narrow, 0.07 to $0.11 \mathrm{~mm}$. long opening at genital pore.

Ovary entire, subspherical or spherical far infront of testes, slightly preequatorial near back of cirrus pouch or away from it, 0.06 to $0.24 \mathrm{~mm}$. long, 0.06 to $0.25 \mathrm{~mm}$. 

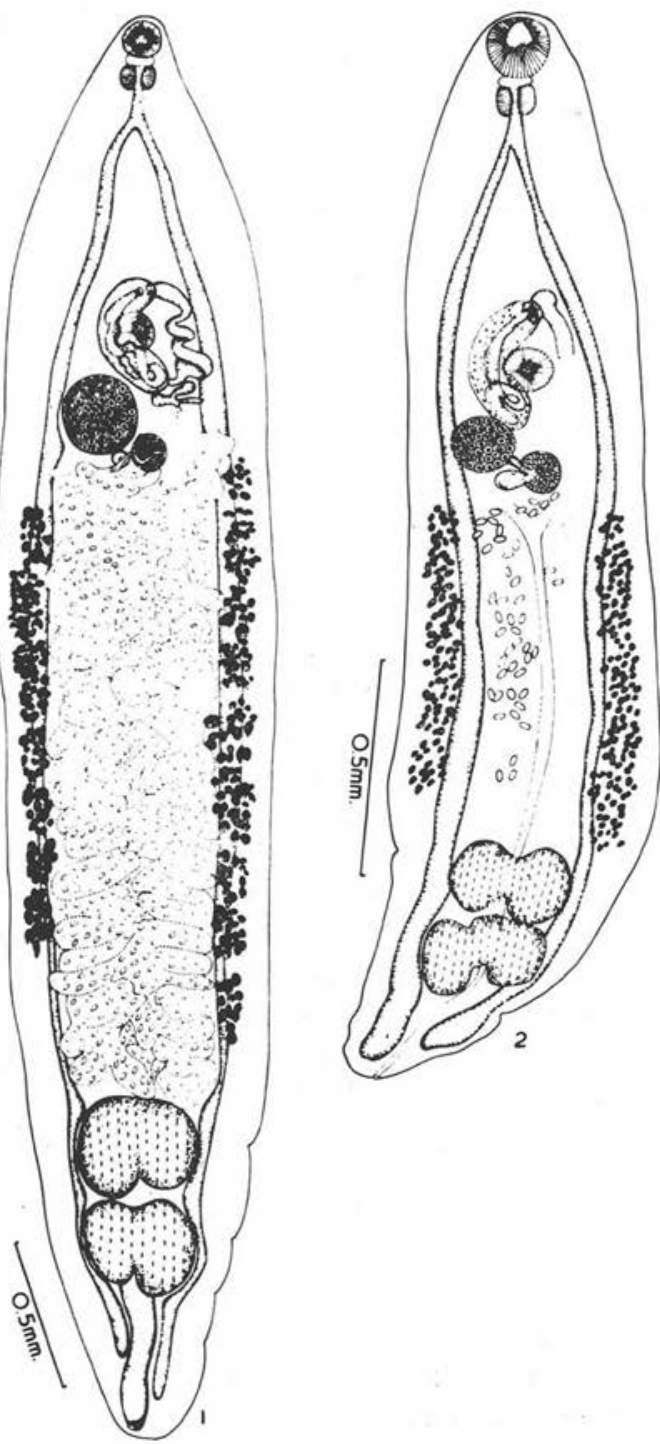

Pl. 3. Figs. 1-2. - Telorchis pellucidus Mehra and Bokhari, 1932

wide at 0.94 to $2.46 \mathrm{~mm}$. from anterior extremity. Receptaculum seminis oval or pear shaped, postovarian, 0.03 to $0.15 \mathrm{~mm}$. long, 0.03 to $0.20 \mathrm{~mm}$. wide at 0.07 to $1.67 \mathrm{~mm}$. from anterior extremity. Mehli's gland lies just behind ovary, 0.05 to 0.06 $\mathrm{mm}$. long, 0.06 to $0.07 \mathrm{~mm}$. wide. Vitellaria follicular, grouped like grape bunches 
mostly extracaecal, extending from a little posterior to ovary upto a little anterior or upto level of anterior testis. Uterus with long ascending and descending limbs, intercaecal to region infront of testes, ending in a muscular metraterm. Eggs oval, non operculated, 0.02 to $0.04 \mathrm{~mm}$. long, 0.01 to $0.02 \mathrm{~mm}$. wide.

Host : Kachuga dhongoka (Gray).

LOCATION : Intestine.

LOCALITY : Lucknow.

Discussion : The present form belongs to Telorchis pellucidus Mehra and Bokhari, 1932, but however differs from it in being smaller in body size, in the possession of a prepharynx and in having anterior testis equal or smaller to posterior testis instead of being equal. These differences are considered as specific variations.

\section{Telorchis dbongokii Mehra and Bokhari, 1932 \\ Plate 3 (Fig. 3)}

Three immature specimens were collected from the intestine of Kachuga dhongoka from river Gomati at Lucknow.

Description : Body slender, elongated with rounded extremities, 2.26 to $3.70 \mathrm{~mm}$. long, 0.38 to 0.42 wide. Cuticle covered with spines extending back to level of anterior testis. Oral sucker subterminal, spherical, 0.10 to $0.13 \mathrm{~mm}$. long, 0.12 to $0.15 \mathrm{~mm}$. wide. Prepharynx small and thin walled, 0.02 to $0.03 \mathrm{~mm}$. long. Pharynx spherical or globular, 0.07 to $0.09 \mathrm{~mm}$. long, 0.10 to $0.08 \mathrm{~mm}$. wide Esophagus slender, 0.04 to $0.14 \mathrm{~mm}$. long. Intestinal caeca simple, slender, crenated, extending at unequal levels behind posterior testis. Ventral sucker spherical or subspherical, smaller than oral sucker, median or slightly to one side, 0.1 to $0.2 \mathrm{~mm}$. long, 0.10 to $0.11 \mathrm{~mm}$, wide at 0.46 to $0.98 \mathrm{~mm}$. from anterior extremity.

Genital pore median or submedian, preacetabular at 0.50 to $0.80 \mathrm{~mm}$. from anterior extremity. ovary.

Excretory pore at hind end of body. Excretory bladder not conspicuous behind

Testes entire, intercaecal near posterior extremity. Anterior testis equal or smaller than posterior testis, 0.13 to $0.19 \mathrm{~mm}$. long, 0.15 to $0.20 \mathrm{~mm}$. wide at 1.76 to 3.08 $\mathrm{mm}$. from anterior extremity. Posterior testis 0.14 to $0.21 \mathrm{~mm}$. long, 0.15 to $0.20 \mathrm{~mm}$. wide at 0.04 to $0.15 \mathrm{~mm}$. from hind end. Cirrus pouch elongated extending upto posterior to ovary or upto middle of ventral sucker and ovary, 0.50 to $0.90 \mathrm{~mm}$. long, 0.06 to $0.09 \mathrm{~mm}$. wide.

Ovary entire, subspherical or spherical, far from testes, postequatorial, 0.08 to $0.085 \mathrm{~mm}$. long, 0.08 to $0.10 \mathrm{~mm}$. wide at 1.05 to $1.97 \mathrm{~mm}$. from anterior extremity. Receptaculum seminis oval, post ovarian, 0.03 to $0.05 \mathrm{~mm}$. long, 0.03 to $0.06 \mathrm{~mm}$. wide at 1.36 to $2.05 \mathrm{~mm}$. from anterior extremity. Mehli's gland lies just behind 
ovary $0.35-0.55 \mathrm{~mm}$. long, 0.35-0.6 mm.wide. Vitellaria follicular, mostly extracaecal, extending from middle of ventral sucker and ovary upto anterior testis. Uterus with long ascending and descending limbs intercaecal to region in front of testes ending in a muscular metraterm.

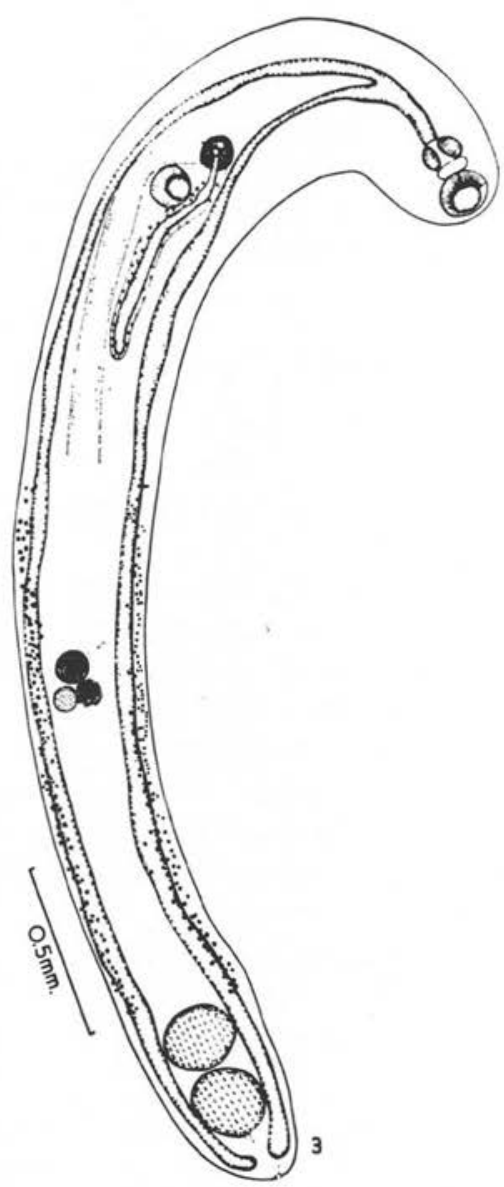

PI. FIG. 3. - Telorchis dhongokii Mehra and Bokhari, 1932

Host : Kachuga dhongoka (Gray).

LOCATION : Intestine.

Locality : Lucknow. 
Discussion : The present form belongs to Telorchis dhongokii Mehra and Bokhari, 1932, but however differs from it in the possession of a prepharynx, in having oral sucker larger than ventral sucker and in having well-developed receptaculum seminis. These differences are considered as specific variations.

\section{Bibliography}

Chatterji (R.C.), 1936. - The Helminth parasites in the fresh water turtles of Rangoon. Rec. Ind. Mus., 38: 81-94.

Gupta (N. K.), 1954. - On three new species of the genus Cephalogonimus Poirier, 1886, from the intestine of Lissemys punctata punctata. Res. Bull. Punj. Univ., 49-55: 71-100.

Mehra (H. R.) et Bokhari (M. A.), 1932. - On new distome trematodes from the subfamily Telorchiinae (Family Lepodermatidae), with a systematic discussion of its genera. Alld. Univ. Stud., $8: 47-68$.

Mehra (H. R.), 1932. - Nouveaux monostomes de la famille des Pronocephalidae des tortues d'eau douce de l'Inde, classification de cette famille. Ann. Par., 10; 225-247.

Siddiei (H. A.), 1965. - Two new trematodes from fresh water turtles in India. Jour. Helminth., 39: 277-280.

Yamaguti (S.), 1958. - Systema Helminthum, Interscience Publishers, New York, London. Vol. 1 \& 2: 1-979. 